\title{
Early Dynastic Bead Workshops at the Central Kom of Tell el-Farkha
}

\author{
MAREK CHŁODNICKI
}

\begin{abstract}
In 2002, specialized workshops with micro-perforators (microdrills) were found at Tell el-Farkha. The material was well described as seven separate units. Further analysis shows that originally they formed only two separate workshops. Each workshop occupies a similar space. Although we did not find any finished products or raw material in direct association with the implements, it seems that as on the other sites they were used for bead production.
\end{abstract}

Keywords: Early Dynastic Egypt, bead workshop, microdrills

Marek Chłodnicki, Poznań Archaeological Museum, Poznań; mchlod@man.poznan.pl

Agate and carnelian beads are a very common find at Tell el-Farkha. Beads and amulets made of various stones such as steatite, serpentinite, limestone, amethyst, rock crystal, agate and hematite occur, but ones made of carnelian dominate (Figs 1-2). We discovered them in graves as well as in deposits in the administrative-cultic center in the Western Kom. The carnelian and ostrich-eggshell beads were hidden together with the golden figurines on the Eastern Kom. Some amount, not insignificant, was found also scattered around the settlement on all three koms. The oldest collection of stone beads was found at the Lower Egyptian residence on the Central Kom (Naqada IID), but they are most abundant in Early Dynastic times. ${ }^{1}$

Most of the beads were imported to Tell el-Farkha as a ready product. Some of them could have been produced locally, at least in Early Dynastic times. This is perhaps indicated by the concentrations of microdrills and the presence of raw materials on the site. Collections of microdrills discovered on other sites have been interpreted in this way.

The biggest collection of this kind of small implements is known from Hierakonpolis. ${ }^{2}$ In 1899 F.W. Green found in two caches an enormous number of exceedingly small pointed

\footnotetext{
${ }^{1}$ Chłodnicki, Geming 2012: 97-98; Chłodnicki et al. 2014: 134-138.

${ }^{2}$ Quibell, Green 1902: 11; Adams 1974: 30-31; Holmes 1992: 41-42; Hikade 2004: 188-191.
} 


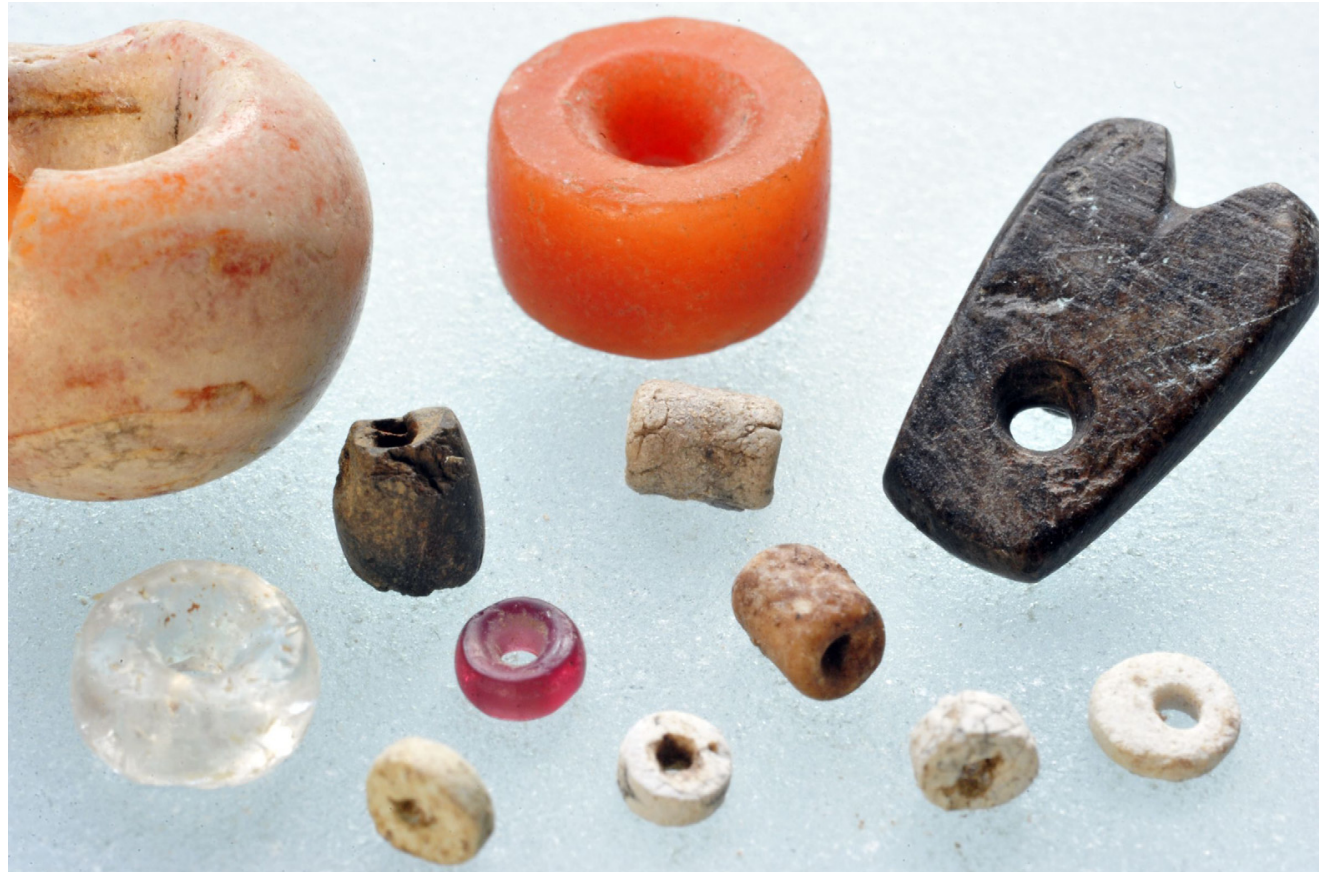

1. Stone beads found at the Central Kom in the Early Dynastic strata (Phot. R. Słaboński).

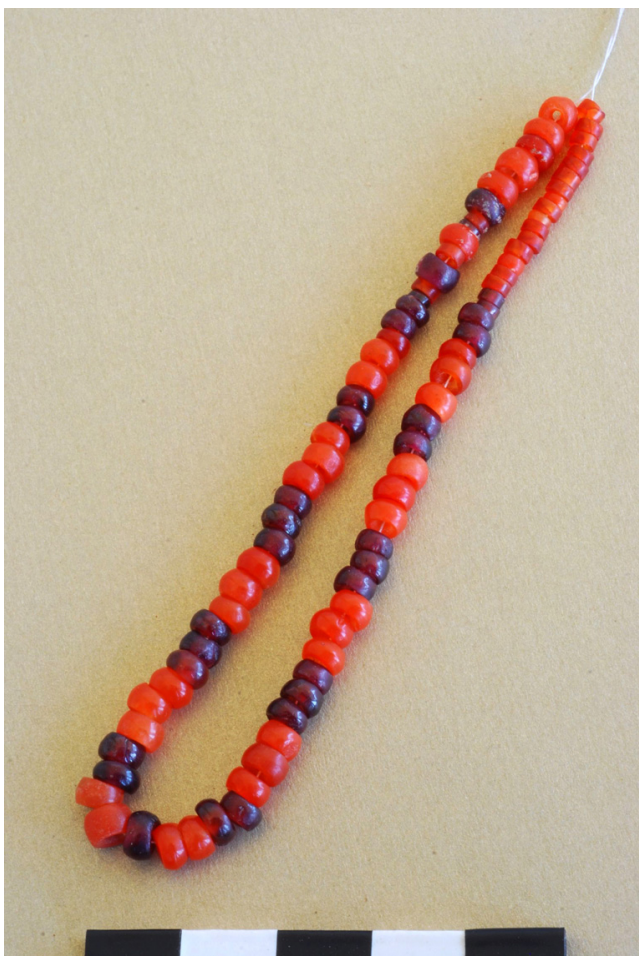

2. Carnelian beads from grave no. 98 (Phot. R. Słaboński). 
flints as well as broken carnelian pebbles, some of which had been formed into roughly shaped beads. ${ }^{3}$ Selected items (464 microdrills and several unfinished beads) from one cache were sent to the Petrie Museum UCL. ${ }^{4}$

More of these microdrills were found at the ceremonial center Hk29a in Hierakonpolis where several hundred small borers were discovered. These were made of bladelets, which occur together with cores, and other debitage products associated with their manufacture, like a few unfinished stone beads which also occur at the site along with small flakes and chips of carnelian and other materials. D. Holmes suggests that although microdrills had more than one function it seems that their main use was manufacture of stone beads. ${ }^{5}$

At square $10 \mathrm{~N} 5 \mathrm{~W}$ at Hierakonpolis, complete carnelian pebbles, pieces of carnelian and a core were excavated. Several carnelian nodules were reduced to small semi-hemispherical pieces or square blocks of a size which could suggest that they were performed for beads. ${ }^{6}$ Thirty-three microdrills made on bladelets or small flakes and about 100 tiny chips made of grayish-brown heterogeneous raw materials were also found there. T. Hikade ${ }^{7}$ distinguished three groups among the microdrills. The first is a type with a more elongated outline up to $4 \mathrm{~cm}$ long and a pronounced working edge, the second has a very pointy tip and broad basal end and the third is a short and robust variant with a small pointed tip.

A collection of microdrills is also known from Abydos. Over three hundred borers were found there in the centre of the settlement together with unworked agate and carnelian. The length of perforators varies from 16 to $48 \mathrm{~mm}$ and many of the specimens were broken. ${ }^{8}$

Specialized workshops with micro-perforators (microdrills) were discovered also in 2002 at the Central Kom of Tell el-Farkha. These were published as three concentrations of flint with microdrills ${ }^{9}$ and classified as Early Dynastic (Naqada IIIB-C) perforator workshops. An inventory of each workshop from a technological and typological point of view was characterized by J. Kabaciński and P. Szejnoga, but nothing was mentioned about the context of these finds. The material was most abundant in workshop 1 (feature C.234) - 1010 artefacts. A smaller number of flints was discovered in workshop $2-389$ pieces (feature C.239) and workshop 3 - 588 pieces (feature C.232).

In the later publication four other, smaller, workshops were mentioned: workshop $4-337$ pieces, workshop $5-139$ pieces, workshop $6-100$ pieces and workshop $7-97$ pieces. $^{10}$

\footnotetext{
${ }^{3}$ Quibell, Green 1902: 11.

${ }^{4}$ Endo, Takamiya, Friedman 2009.

5 Holmes 1992: 41-42, Fig. 4d-f.

${ }^{6}$ Hikade 2004: 188-189.

7 Hikade 2004: 190-191.

8 Peet 1914: 3-4, Pl. 3a.

${ }_{9}$ Chłodnicki et al. 2007; Kabaciński 2012: 339-344.

10 Kabaciński 2012: Tabs 1-2.
} 


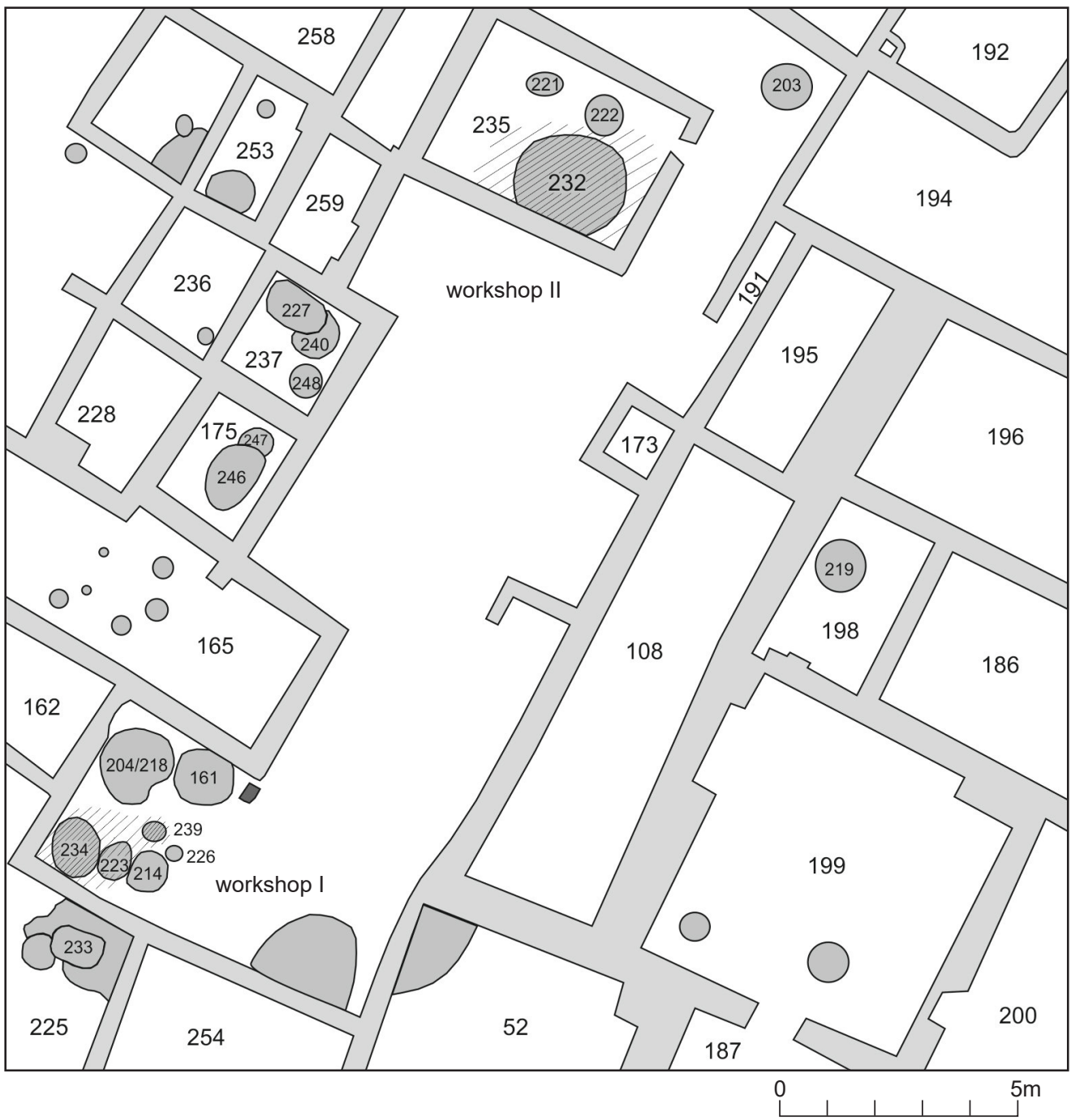

3. Central Kom. Location of the workshops I and II (Drawing: M. Chłodnicki).

When all seven concentrations were mapped we realized that originally they formed only two workshops. The first of them (workshop I) contain flint concentrations numbered as workshops 1, 2 and 4, whereas the second (workshop II) consists of previous workshops $3,5,6$ and 7 .

Both workshops were located in the passage between the dwelling area, where bigger houses are arranged around the courtyards and the economic area, with much smaller rooms, on the border of the village (Fig. 3). Workshop I contains two fireplaces and is placed in the area surrounded from three sides by walls. It is opened to the east, with a huge stone block on the entrance. The room has about $3 \times 3.5 \mathrm{~m}$, but the flints were 


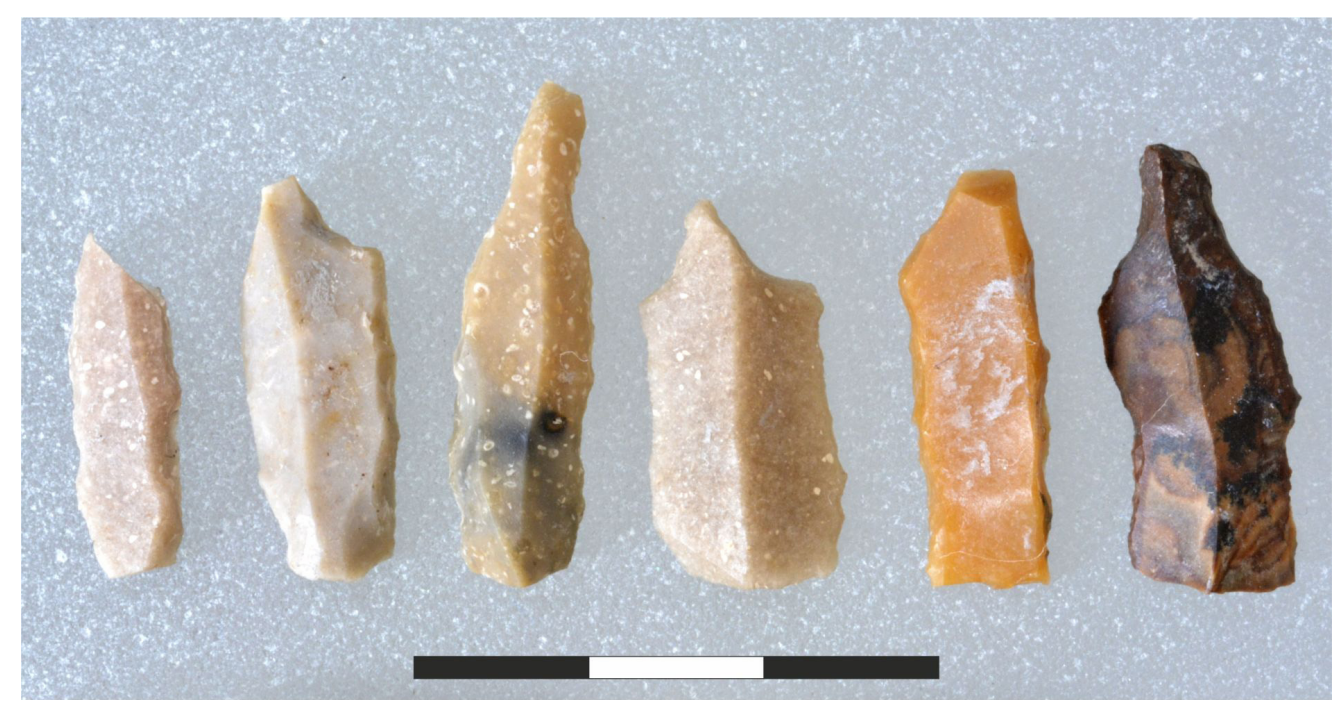

4. Selection of microdrills from Central Kom (Phot. J. Skłucki).

concentrated only in an area of about $2 \times 3 \mathrm{~m}$ in the southern part - in the fireplaces and around them.

The second workshop was surrounded by the walls from all four sides. The big room has $3 \times 4 \mathrm{~m}$, but the flints were concentrated also only in an area of $2 \times 3 \mathrm{~m}$ in the south-eastern corner. Most of the flints were discovered in the fireplace.

These were produced mostly from grey to dark brown flint often with dotted and patched calcareous intrusions, rarely brown to light brown flint, without intrusions. In the workshops flakes and chips resulting from the core reduction were predominant. The cores were small and mostly used for removing small blades. Most of them were single-platform cores which were heat-treated for technological reasons. The most common blades are approximately $30-40 \mathrm{~mm}$ long, 5-7mm wide and $2-3 \mathrm{~mm}$ thick (Figs 4-5). ${ }^{11}$ It seems that there were no microdrills of Hikade's first type and that the third type is the most common.

About $10-15 \%$ of the assemblages are tools (Tab. 1), mostly (60-92\%) micro-perforators (microdrills). Together, 284 microdrills were found in the workshops. They have well-defined stings, with semi abrupt retouching on their dorsal face. They can be divided into categories depending on location of the sting on the bladelet and form of the base. ${ }^{12}$ In each workshop the number of pieces representing particular types varies, which may reflect the specific preferences of the flint-knapper. For example, in workshop I microdrills with a retouched base were preferred, whereas in workshop II it was the ones with a snapped base (Tab. 2).

\footnotetext{
11 Chłodnicki et al. 2007: 85; Kabaciński 2012: 340.

12 Chłodnicki et al. 2007: 85; Kabaciński 2012: 341.
} 

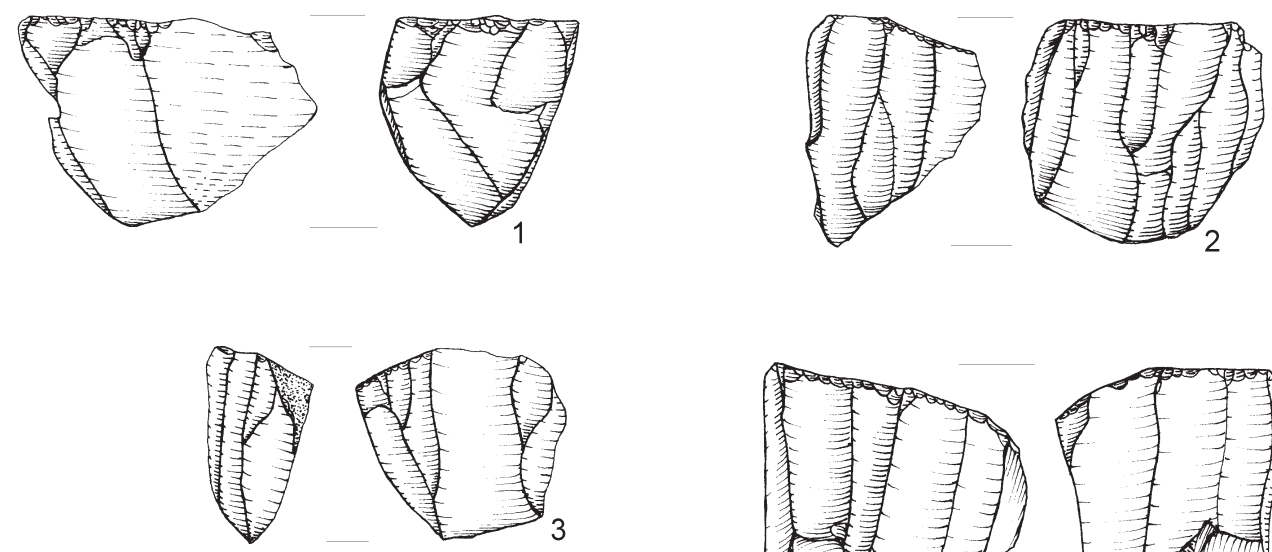

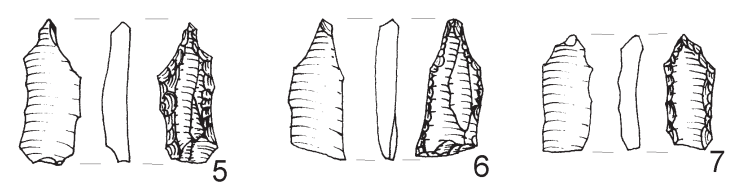
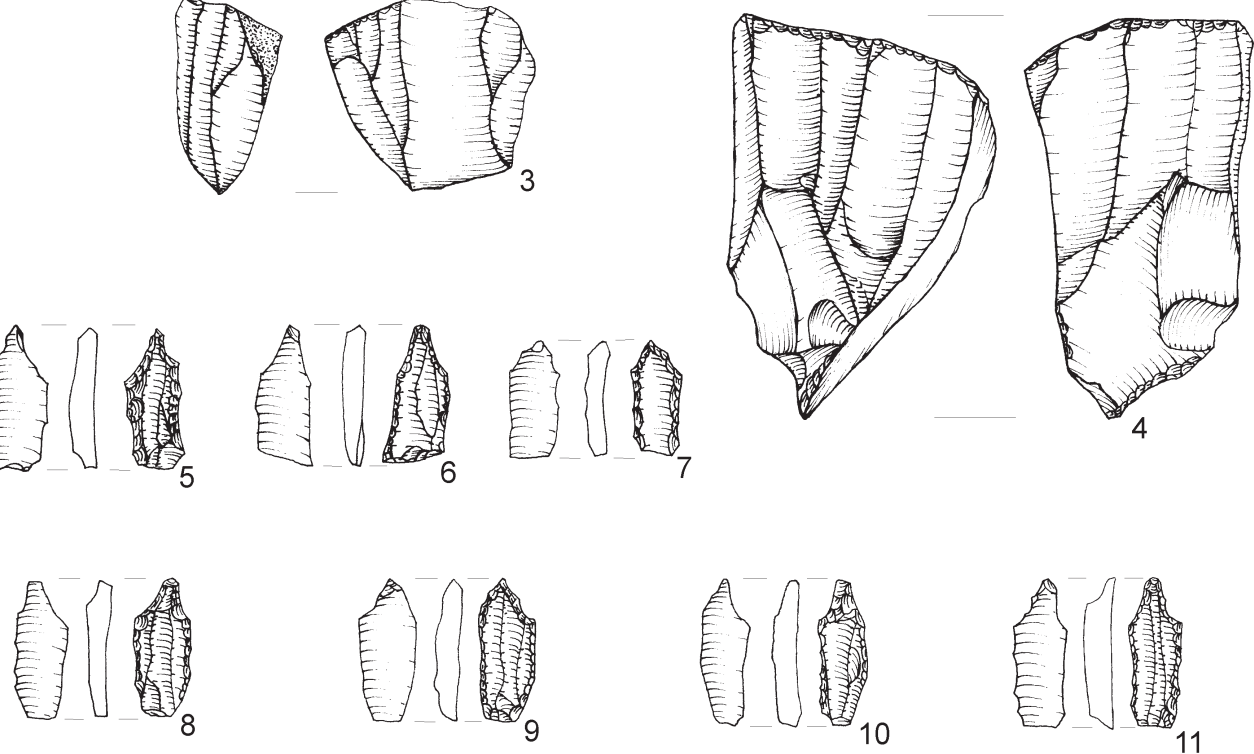

县-
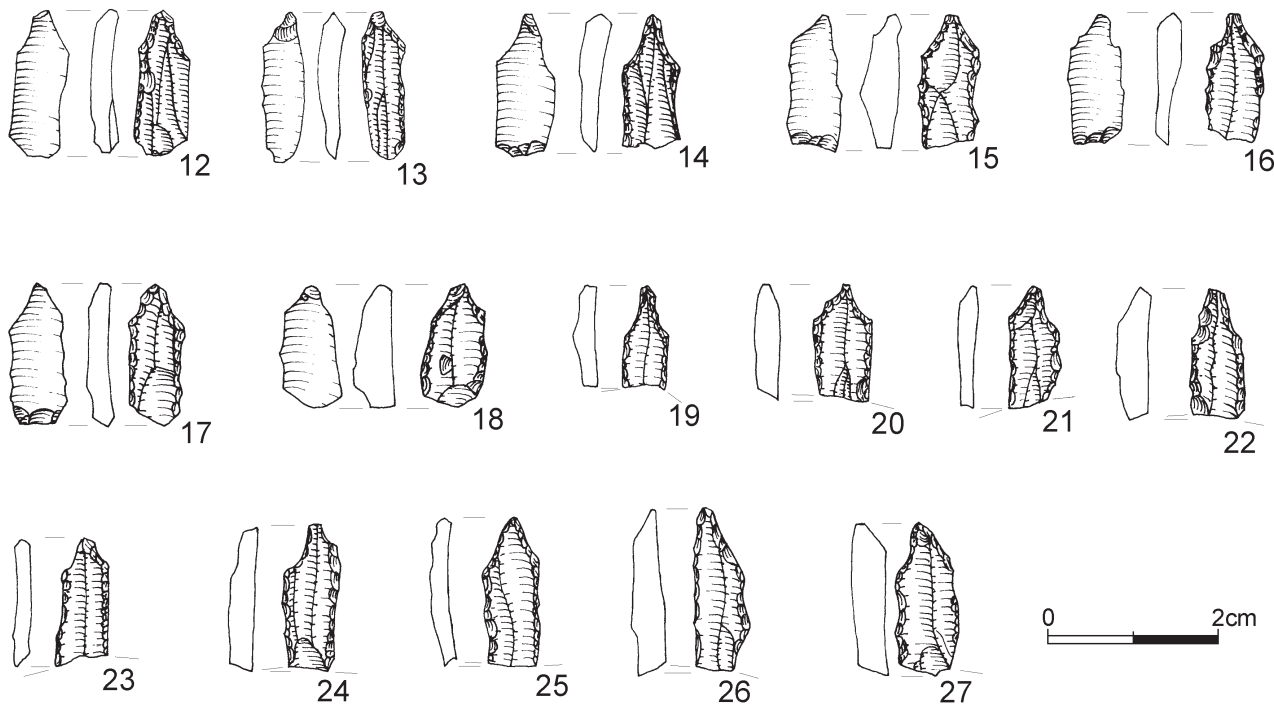

5. Cores and micro-perforators (microdrills) from workshop 3 (II) (Kabaciński 2012: Fig. 18). 
Tab. 1. General technological structure of workshops (based on: Kabaciński 2012: Tab. 1)

\begin{tabular}{|c|c|c|}
\hline Category & $\begin{array}{c}\text { WORKSHOP I } \\
\text { Workshops } 1+2+4\end{array}$ & $\begin{array}{c}\text { WORKSHOP II } \\
\text { Workshops } 3+5+6+7\end{array}$ \\
\hline \multicolumn{3}{|c|}{ Group I - preparation and initial exploitation of the cores } \\
\hline Cortex flakes & 34 & 15 \\
\hline Cortex blades & 18 & 14 \\
\hline Primary crested blades & 9 & 2 \\
\hline Core trimming flakes & 10 & 2 \\
\hline \multicolumn{3}{|c|}{ Group II - production of flakes } \\
\hline Single platform cores on flakes & - & 3 \\
\hline Flakes from single platform cores & 52 & 30 \\
\hline Flakes from opposed platform cores & 22 & 3 \\
\hline Flakes from cores with changed orientation & 2 & 2 \\
\hline \multicolumn{3}{|c|}{ Group III - production of blades } \\
\hline Single platform cores for blades & 6 & 5 \\
\hline Blades from single platform cores & 192 & 141 \\
\hline Opposed platform cores for blades & 2 & 1 \\
\hline Blades from opposed platform cores & 10 & 7 \\
\hline Cores for blades with changed orientation & 7 & 1 \\
\hline Blades from cores with changed orientation & 3 & 1 \\
\hline \multicolumn{3}{|c|}{ Group IV - repairs } \\
\hline Core tablets & 5 & 3 \\
\hline Secondary crested blades & 6 & 21 \\
\hline \multicolumn{3}{|c|}{ Group V - production of tools } \\
\hline Tools & 190 & 156 \\
\hline Burin spalls & 2 & - \\
\hline Flakes from production bifaces & 8 & - \\
\hline \multicolumn{3}{|c|}{ Group VI - unidentified and fragments } \\
\hline Unidentified flakes & 10 & 5 \\
\hline Unidentified blades & 3 & 1 \\
\hline Unidentified cores and fragments & - & 1 \\
\hline Chips & 1052 & 484 \\
\hline Chunks & 93 & 26 \\
\hline Total & 1736 & 924 \\
\hline
\end{tabular}


Tab. 2. Typological structure of perforators from workshops I and II (based on: Kabaciński 2012: Tab. 2)

\begin{tabular}{|l|c|c|c|c|}
\hline \multicolumn{1}{|c|}{ Category } & \multicolumn{2}{c|}{$\begin{array}{c}\text { WORKSHOP I } \\
\text { Workshops 1+2+4 }\end{array}$} & \multicolumn{2}{c|}{$\begin{array}{c}\text { WORKSHOP II } \\
\text { Workshops 3+5+6+7 }\end{array}$} \\
\cline { 2 - 5 } & amount & $\%$ & amount & \multicolumn{2}{c|}{$\%$} \\
\hline $\begin{array}{l}\text { Micro-perforators with natural base and sting located in } \\
\text { proximal part of bladelet }\end{array}$ & 4 & 2.5 & 3 & 2.3 \\
\hline $\begin{array}{l}\text { Micro-perforators with sting located in distal part of } \\
\text { bladelet and natural base with preserved bulb }\end{array}$ & 41 & 26.1 & 28 & 22.0 \\
\hline Micro-perforators with retouched base & 49 & 31.2 & 22 & 17.3 \\
\hline Micro-perforators with snaped base & 9 & 5.7 & 65 & 51.3 \\
\hline Unidentified perforators and fragments & 4 & 34.5 & 9 & 7.1 \\
\hline Total & $\mathbf{1 5 7}$ & $\mathbf{1 0 0 . 0}$ & $\mathbf{1 2 7}$ & $\mathbf{1 0 0 . 0}$ \\
\hline
\end{tabular}

The size of the implements was very uniform. They are $10-19 \mathrm{~mm}$ long, $4-7 \mathrm{~mm}$ wide and $2-4 \mathrm{~mm}$ thick. Their width and thickness corresponds to the dimensions of the most frequent blades produced at the workshops. The stings of the micro-perforators are heavily reduced as a result of intensive use and the tips often exhibits signs of having been crushed. The implements were definitely produced and used in the same place. ${ }^{13}$

Although we did not find agate fragments or unfinished beads in the workshops at the Central Kom, the workshop discovered in 2004 at the Eastern Kom could confirm that agate was used locally for bead production. That workshop is a bit older (Naqada IIIA2-IIIB) and takes the form of a pit of a diameter of about $1.5 \mathrm{~m}$ and $10 \mathrm{~cm}$ deep (feature EN.92), filled mostly with stone debitage. 391 objects were discovered there, with one third of the collection being agate fragments - raw material nodules and cores. Quartz hammer stones and sandstone polishers were also found there, but only three micro-perforators were recorded. ${ }^{14}$ The concentration of agate fragments was surprising. It seems that they were collected for the bead production.

Although we do not have all phases of bead production process in one place, it seems that the stone beads could be manufactured at the site. It is also possible that the microdrills were used for other purposes - for drilling holes in other materials as bone or pottery. But, in such a case, it is not necessary to have so many implements in the one place. Only boring holes in hard stones needs to use many micro-drills. Moreover, carnelian pieces found on the site, material locally unavailable, suggest that they were brought for bead production.

\footnotetext{
13 Chłodnicki et al. 2007: 86; Kabaciński 2012: 343.

${ }^{14}$ Chłodnicki et al. 2007: 90-91, Tab. 4.
} 


\section{References}

Adams, B. 1974: Ancient Hierakonpolis, Warminster

Chłodnicki, M., Ciałowicz, K.M., Abłamowicz, R., Cichowski, K., Dębowska-Ludwin, J., Jucha, M.A., Kabaciński, J., Kaczmarek, M., Pawlikowski, M., Pryc, G., Rewekant, A., Skrzypczak, M., Szejnoga, P., Wasilewski, M. 2007: Polish Excavations at Tell el-Farkha (Ghazala) in the Nile Delta. Preliminary Report 2004-2005, Archeologia (V) LVII, 71-128

Chłodnicki, M., Ciałowicz, K.M., Bąk-Pryc, G., Dębowska-Ludwin, J., Jucha, M., Rosińska-Balik, K., Sobas, M. 2014: Polish Excavations at Tell el-Farkha (Ghazala) in the Nile Delta, Preliminary Report 2011-2013, Archeologia (V) LXIV, 99-140

Chłodnicki, M., Geming, M.M. 2012: Lower Egyptian settlement on the Central Kom, [in:] Chłodnicki, M., Ciałowicz, K.M., Mączyńska, A., Tell el-Farkha I: Excavations 1998-2011, Poznań-Kraków, 89-104

Endo, H., Takamiya, I., Friedman, R. 2009: Interactive Dig Hierakonpolis 2009 - Field Note 3 - Beads and Bead Making at Hierakonpolis, http://interactive.archaeology. org/hierakonpolis/field09/3.html (accessed November 19, 2015)

Hikade, T. 2004: Urban development at Hierakonpolis and the stone industry of square 10N5W, [in:] Hendrickx, S. et al. (Eds), Egypt at Its Origins: Studies in Memory of Barbara Adams. Proceedings of the International Conference "Origin of the State. Predynastic and Early Dynastic Egypt”, Krakow, 28 ${ }^{\text {th }}$ August - $1^{\text {st }}$ September 2002, OLA 138, Leuven-Paris-Dudley, MA, 181-197

Holmes, D.L. 1992: Chipped Stone-Working Craftsmen, Hierakonpolis and the Rise of Civilisation in Egypt, [in:] Friedman, R. Adams, B. (Eds), The Followers of Horus: Studies Dedicated to Michael Allan Hoffman, 1944-1990, Oxbow Monograph 20, Oxford, 37-44

Kabaciński, J. 2012: Selected aspects of lithic production, [in:] Chłodnicki, M., Ciałowicz, K.M., Mączyńska, A., Tell el-Farkha I, Excavations 1998-2011, Poznań-Kraków, 323-344

Peet, T.E. 1914: The Cemeteries of Abydos II: 1911-1912, MEEF 34, London

Quibell, J.E., Green, F.W. 1902: Hierakonpolis II, ERA 5, London 


\section{ÉTUDES et TRAVAUX XXX / 2017}

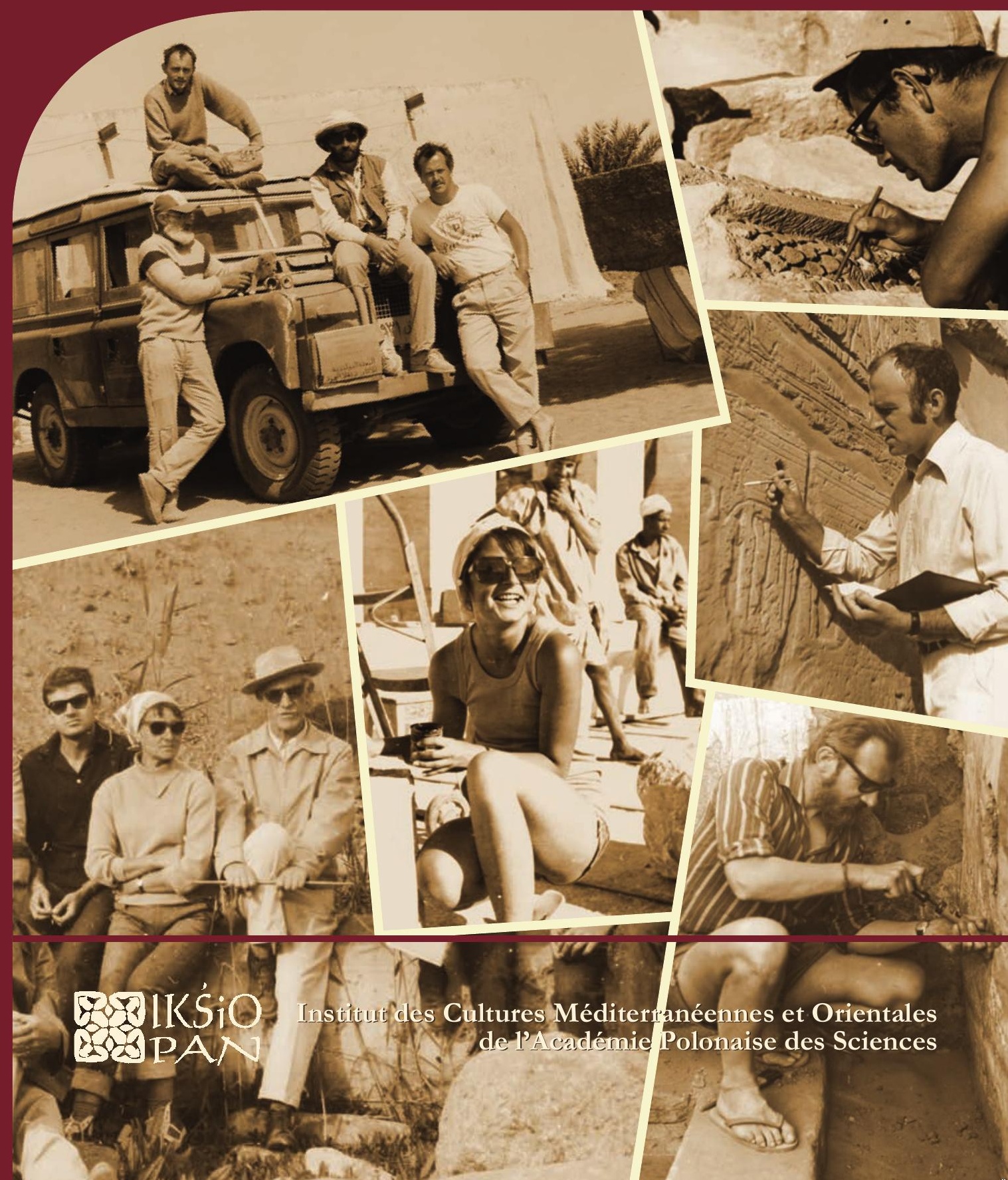




\title{
COMITÉ DE RÉDACTION SCIENTIFIQUE
}

Maciej Makowski - rédacteur en chef

Jadwiga Iwaszczuk - rédacteur et sécretaire de la rédaction

Mariusz Drzewiecki - rédacteur

Maciej G. Witkowski - rédacteur

\section{CONSEIL SCIENTIFIQUE DU JOURNAL}

M. Kobusiewicz (IAE PAS, Warszawa), E. Laskowska-Kusztal (IMOC PAS, Warszawa),

D. Michaelides (University of Cyprus, Nicosia),

J.Ch. Moretti (IRAA-MOM, Université de Lyon 2/CNRS),

D. Raue (Ägyptisches Museum der Universität Leipzig), P. Reynolds (ICREA, Barcelona),

D. Welsby (British Museum, London)

\section{COMITÉ SCIENTIFIQUE DE LECTURE}

J. Holaubek (Institut für Ägyptologie, Wien), S. Ikram (AUC, Cairo),

K. Innemée (Universiteit Leiden), J. McKenzie (Faculty of Oriental Studies, University of Oxford),

N. Strudwick (University of Cambridge), A. Loprieno-Gnirs (Universität Basel),

Ch.E. Loeben (Museen für Kulturgeschichte, Hannover), Y. Tristant (Macquarie University, Sydney),

V.W.J. van Gerven Oei (University of Aberdeen), A. Peignard-Giros (HiSoMA-MOM, Université de Lyon 2/CNRS), J.A. Ostrowski, E. Papuci-Władyka, J. Śliwa (IA JU, Kraków), R. Czerner (WUST, Wrocław), A. Ćwiek (IA AMU, Poznań), M. Wiewióra (IA NCU, Toruń), K. Domżalski

(IAE PAS, Warszawa), K.O. Kuraszkiewicz (DE FOS UW), M. Barwik, P. Bieliński, P. Dyczek, W. Godlewski, D. Ławecka, S. Rzepka, J. Żelazowski, M. Gawlikowski, J. Młynarczyk, A. Niwiński, T. Sarnowski, D. Szeląg, T. Waliszewski (IA UW, Warszawa)

\section{RÉDACTEUR THÉMATIQUE DU VOLUME \\ Barbara Lichocka}

\author{
AIDE RÉDACTION TECHNIQUE \\ Dorota Dobrzyńska, Mariusz Drzewiecki
}

REVUE DES TEXTES ANGLAIS

Jo Harper 
ÉTUDES et TRAVAUX XXX 
INSTYTUT KULTUR ŚRÓDZIEMNOMORSKICH I ORIENTALNYCH POLSKIEJ AKADEMII NAUK

\section{STUDIA i PRACE}

XXX

\section{Ro IKŚSiO \\ ESA PAN}

WARSZAWA

2017 
INSTITUT DES CULTURES MÉDITERRANÉENNES ET ORIENTALES DE L'ACADÉMIE POLONAISE DES SCIENCES

\section{ÉTUDES et TRAVAUX}

XXX

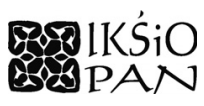

VARSOVIE

2017 
Publication scientifique financée dans le cadre du programme du Ministre de la Science et de l'Éducation Supérieure

« Programme National de Développement de l’Humanistique » pour les années 2016-2021 (projet no 3bH 150099 83)

\title{
HARODOWY PROGRAM ROZWOJU HUMANISTYKI
}

\author{
Copyright (C) \\ Instytut Kultur Śródziemnomorskich i Orientalnych PAN \\ et les Auteurs \\ Warszawa 2017
}

\author{
ISSN 2084-6762 \\ (avant $2011: 0079-3566$ ) \\ e-ISSN 2449-9579 \\ Version première en papier, imprimée en Pologne - 150 copies \\ Version électronique accessible sur \\ http://www.etudesettravaux.iksiopan.pl
}

Édition: Polskie Towarzystwo Historyczne et Wydawnictwo Neriton, Warszawa

Conception générale de couverture : J. Iwaszczuk

Photos de couverture : En haut, à gauche. Vieille Dongola 1991, S. Jakobielski

(debout à gauche), K. Pluskota (debout à droite), B. Żurawski (assis sur le camion)

et P. Wierzbicki (assis sur le camion) (de la collection de B. Żurawski)

En haut, à droite. Palmyre 1964, M. Marciniak au travail (phot. A. Dziewanowski)

Au centre. E. Laskowska-Kusztal au travail (de la collection de E. Laskowska-Kusztal)

En bas, à gauche. Tell Atrib 1962 ; de gauche : T. Biniewski, M. Marciniak, K. Kołodziejczyk,

K. Michałowski, A. Ostrasz, S. Jakobielski et S. Jasiewicz devant eux

(de la collection de IKŚSiO PAN).

En bas, à droite. Vieille Dongola 1976, S. Jakobielski nettoyant le mur (phot. M. Steinborn).

Au centre, à droite, K. Myśliwiec en train des travaux de documentation (de la collection de IKŚiO PAN) 


\section{Table des matières}

BARBARA LICHOCKA

Ergon agathon

Hartwig Altenmüller

$\mathrm{Zu}$ den Feindbildern auf den Zauberstäben des Mittleren Reiches und der Zweiten

Zwischenzeit

Nathalie Beaux

Des $m s w n s w$ de Thoutmosis III à Deir el-Bahari

Briant Bohleke, Nigel Strudwick

A Label for Opening of the Mouth Implements from the Burial of Senneferi (TT99)

and Remarks on the Ritual

Rosa Maria Bonacasa Carra, Nicola Bonacasa

Nuovi dati sugli edifici termali di Sabratha

EDWARD BROVARSKI

A Fragmentary Carrying Chair Scene in Salt Lake City, Utah

Julia Burdajewicz

Wall Painting Decoration from the North-West Church in Hippos-Sussita

of the Decapolis

Mariusz BURDAJEWICZ

From Pagan Temple to Church in Late Antiquity Palestine. A View from

Hippos-Sussita

MAREK ChlodNicki

Early Dynastic Bead Workshops at the Central Kom of Tell el-Farkha.

Patryk ChudziK, Mariusz Caban

Observations on the Architecture of the Tomb of Horhotep in Western Thebes

Krzysztof M. Cialowicz

New Discoveries at Tell el-Farkha and the Beginnings of the Egyptian State.

Amr EL-TiebI

Four Wooden New Kingdom Female Statuettes in the Egyptian Museum, Cairo 


\section{Naguib KanaWATI}

Ritual Marriage Alliances and Consolidation of Power in Middle Egypt during the Middle Kingdom

Adam Łajtar, Jolanta Mlynarczyk

A Faction Acclamation Incised on a Pithos Found Near the North-West Church at Hippos (Sussita)

Adam ŁaJTAR, Grzegorz OchaŁa

Two Private Prayers in Wall Inscriptions in the Faras Cathedral

Adam Łajtar, Anna Poludnikiewicz

Medicinal Vessels from Tell Atrib (Egypt)

JaCeK Michniewicz, Jolanta MlynarczyK

Petrographic Variability of the Fabrics of Wine Jars from Sha'ar-Ha Amakim as a Reflection of Differences in Their Provenance and Chronology

Iwona ModrzewsKa-PianetTI

Les importations d'amphores Dressel 20 en Gaule Cisalpine

Arthur SEgal

Samaria-Sebaste. Portrait of a polis in the Heart of Samaria 409

JOACHIM ŚLIWA

The Motif of a 'Blind Harper' in an Unexpected Place

MONIKA WIĘCH

Searching for the Kitchen in the Early Roman Phase of the 'Hellenistic' House at Nea Paphos (Cyprus)

Abréviations 
THE VOLUME IS PUBLISHED TO CELEBRATE

THE $60^{\text {TH }}$ ANNIVERSARY

OF THE ESTABLISHMENT OF

THE RESEARCH CENTRE FOR MEDITERRANEAN ARCHAEOLOGY POLISH ACADEMY OF SCIENCES

FOUNDED IN 1956

WHOSE MISSION IS CONTINUED BY

THE INSTITUTE OF MEDITERRANEAN AND ORIENTAL CULTURES

OF THE POLISH ACADEMY OF SCIENCES 